УДК 82.09

ББК $83.3(0) 4$
СРЕДНЕВЕКОВЫЙ ТЕАТР КАК СРЕДСТВО

КОММУНИКАЦИИ: ИССЛЕДОВАНИЕ

В МЕДИЙНОЙ АРХЕОЛОГИИ

(c) 2017 Э. Дуде

Университет «Гренобль-Альпьl»,

Франиузский Университетский Институт,

Франциия

Дата поступления статьи: І5 октября 2016 г. Дата публикации: 25 марта 2017 г.

DOI: I0.22455/2500-4247-20I7-2-I-44-6I

Аннотация: Медийная археология - это недавно возникшая методология, которая рассматривает средства коммуникации как коммуникативные формы, обусловленные научными инновациями, культурными и социальными ценностями и воображаемыми представлениями. Она также проблематизирует эволюцию и разрывы в развитии медийной культуры начиная от современности, а возможно и в более ранних культурах. В статье предпринята попытка показать, как данная методология позволяет выработать новый подход к теории создания/рецепции текста в истории литературы, а также инновационный способ определения средневековой «медиальности», в ее возможной соотнесенности с более поздними практиками. Французская аллегорическая драма представляет собой случай археологии ви́дения XV и XVI вв. В статье сперва анализируется, как пьесы моралите стремились повлиять на общественное мнение, соединяя оптическое знание и техники с моральным и религиозным образованием. Расширяя визуальные возможности театральных представлений, средневековая аллегорическая драма тем самым подчеркивала, что средство коммуникации и было самим сообщением. Наконец, в статье также исследуются отклики средневековой публики на пьесы с целью показать, как эти пьесы работали и насколько они были влиятельными в действительности.

Ключевые слова: история культуры, перформативные исследования, медийная археология, Средние века и Возрождение.

Информация об авторе: Эстель Дуде, профессор французского языка и французской литературы Средних Веков, Университет «Гренобль-Альпы», Французский Университетский Институт, 38400 Saint-Martin d'Hères, France.

E-mail: estelle.doudet@univ-grenoble-alpes.fr 


\section{MEDIEVAL THEATER \\ AS MEDIUM: A SURVEY IN MEDIA \\ ARCHAEOLOGY}

This is an open access article distributed under the Creative

Commons Attribution 4.0

International (CC BY 4.0)
(C) 20I7. E. Doudet

Université Grenoble Alpes, Institut universitaire de France

Received: October I5, 2017

Date of publication: March 25, 2017

Abstract: Media Archaeology is an emerging methodology that analyses media as modes of communication shaped by scientific innovations, cultural and social values, and imaginary representations. It also questions evolutions and ruptures in Media Cultures from Modernity and possibly before. This paper aims to demonstrate that this method offers a new approach to Production/Reception Theories in History of Literature, and an innovative way to define Medieval 'Mediality', with possible connections to our most recent practices. French allegorical drama offers a case study for an Archaeology of Seeing in the $15^{\text {th }}-16^{\text {th }}$ centuries. The article first analyses how morality plays sought to influence the public's opinion in connecting optical science and technics with moral and religious education. Enhancing the visual possibilities of theatrical performances, Medieval allegorical drama emphathized that the medium was the message. It then investigates the public's various responses to the plays to grasp how they operated and how efficient they really were.

Keywords: History of Culture; Performance Studies; Media Archaeology; Middle Ages and Early Modern Times.

Information about the author: Estelle Doudet, Full Professor of French Language and Literature of the Middle Ages, Université Grenoble Alpes, 38400 Saint-Martin d'Hères, France.

E-mail: estelle.doudet@univ-grenoble-alpes.fr 
For several decades, literature as a mode of communication has been studied via various frames of analysis. The sociology of cultural productions promoted by Bakhtin [4] and Bourdieu [7], and Reception theory initiated by Jauss [I7] and Iser [16], have been deeply influential in literary studies, most markedly during the 'linguistic turn' of the Social and Human Sciences of the I960s-I980s. The beginning of the $2 \mathrm{I}^{\text {st }}$ century saw a paradigm shift with the new development, under Michel Foucault's influence [13], of archaeological approaches to contemporary cultures. Media Archaeology is one of the most stimulating of these emerging methodologies. However, it is still little known and practiced by Medievalists ${ }^{\mathrm{I}}$. A number of reasons can explain this relative lack of interest. On one hand, until now, Media Archaeologists, even if they often refer to famous historians of Medieval culture ${ }^{2}$, have most commonly analyzed Western modes of communication beginning in the $17^{\text {th }}$ and $18^{\text {th }}$ centuries ${ }^{3}$. They have rarely explored the $15^{\text {th }}$ and $16^{\text {th }}$ centuries, not to mention earlier time periods, although these periods offer a wide range of media theorizations, communicative practices and technical innovations ${ }^{4}$. On the other hand, Medievalists, especially those studying literary productions, are used to frames of analysis such as Reception/production theories. Since some of these theories have been elaborated by Medievalists and are well-adapted to the peculiarities of Medie-

\footnotetext{
I A collective volume dedicated to the Cultural History of Media in Middle Ages is being drafted under C. Symes' supervision (Bloomsbury Press). We are grateful to L. Weigert and P. Usher for their comments on the present inquiry.

2 Erkki Huhtamo and Jussi Parikka quote Ernst Robert Curtius, author of the survey

Europäische Literatur und lateinisches Mittelalter (I948) in [25, p. I2].

3 See, for example, E. Huhtamo [15].

4 See P. Usher [3I]. Also see: www.thehumanistanthropocene.net.
} 
val Cultures, experts in that field are not particularly anxious to seek and find new perspectives.

I aim to demonstrate in this paper that Media Archaeology can shed a new light on the specificities of Medieval ways of communication, and contribute to rethinking Reception/Production theories. Moreover, as a specialist of Medieval and Early Modern Performing Arts, I would like to argue that Medieval culture can provide, so to speak, new ground for archaeologists to excavate, and provide the basis to discover and better understand continuities and gaps existing between past and recent Media.

\section{What is Media Archaeology?}

Media History begins its survey in the late $19^{\text {th }}$ century and usually defines 'Mediality' in terms of the emergence of various technicological tools that are able to address a wide, even a worldwide audience. The telegraph, the telephone, the cinema, the radio, the television, the computer, the internet are all both media and mass media. Even if this definition rightly underlines the specificities of contemporary mediality, one may consider that it also restricts the scope of the analysis.

Media Archaeology, first theorized in Germany by Friedrich Kittler [19] and Siegfried Zielinski [34], follows Marshall McLuhan's invitation to analyse Media in much broader terms [24]. This articulation of the field increases the topics of research both thematically and chronologically.

Media Archaeology assumes that 'Mediality' is not limited to concrete apparatuses of one format or another - for example, in the $15^{\text {th }}$ century, manuscript and printed books, glasses and optical medium, etc. - but includes the social practices connected to these objects. Media are influenced by imaginary representations, scientific theories, moral values, sometimes specific to certain milieux, more often commonplaces for large groups who share the same ideal of an efficient communication. These ideas, images, and fantasies are present and active in the media as they operate; they shapes them as actively as they are shaped by them. Even if those who program the communication and those who receive it are not strongly connected, the medium itself could provide information about the effect it is meant to produce - and, hopefully, did produce - on the public.

5 H. R. Jauss first developed his Theory of Literary Genres in reference to Medieval Literature. See H. R. Jauss [I7, p. I07-38]. 
To briefly summarize, one could say that Media Archaeology's method promotes surveys studying works of art as well as technical devices, objects as well as discourses, obsolete materials as well as new technologies. Its project is to developp a new historical approach to media cultures, seeing them "as sedimented and layered'6. Considering Media as machines able to "fold time and materiality," [30, p. 3] archaeologists aim to question their evolution from Modernity, and, as we will argue, possibly before.

\section{Towards An Archaeology of Seeing : the case of Medieval Allegorical Drama}

In a major book published in 2002, Siegfried Zielinski encouraged Media Archaeologists to give particular attention to the multiple and complex history of hearing and seeing [34]. Philosophers have long sought to better understand the operations of both modes of perception; artists and technicians have aspired to increase human visual and auditive potentialities by technical means. The various experiments with optics and audition, once introduced by scholars and specialists, had a gradual impact on ways of thinking and practicing audio-visual communication in Western society. Over time - and Archaeology explores Media Time as a Tiefenzeit, a deep, 'sedimented and layered' time - different regimes of hearing and seeing have developped. Their evolutions often involved what Jay David Bolter et Richard Grusin called a 'Remediation': the constant revival of one media by another, the latter integrating the technical specifics, the social practices and the imaginary representations linked to the former [6].

Drawing on these assumptions within the context of Medieval and Early Modern visual culture, I will focus on allegorical theatre. This performing art, to which I have dedicated my research for several years, offers an interesting case study to evaluate how Media Archaeology can shed light on an ancient mode of communication. I will also argue that, in turn, surveys on Medieval 'Mediality' could help Media Archaeology to expand the scope of its research.

Allegorical drama, also called moral drama, was a performing art flourishing in several European regions between the end of the $\mathrm{I} 4^{\text {th }}$ and the beginning of the $\mathrm{I} 7^{\text {th }}$ century. Depending on the area in which they developed, the plays were known as

6 'Media Archaeology sees media culture as sedimented and layered. <...> It is a way to analyse the regimes of memory and creative practices in Media Cultures, both theoretical and artistic' [30, p. 3]. 
morality plays (England), autos sacramentales (Spain), sacre rappresentazioni (Italy), sinnespelen (Low Countries), or moralités (France).

More than a hundred texts written and, for many of them, performed between I430 and I560 are preserved in French ${ }^{7}$. Most of the moralités staged allegorical characters that usually embodied abstractions of good and evil. The pedagogical objective of the plays was to teach the audience how to behave in everyday life. Consequently, their organizers were required to be invested with a certain legitimacy, as men authorized to speak and perform in public. The moralizing goal of such plays also implied a topical rhetoric. On the stage, wellk-nown characters illustrated recurring ideas through commonplaces; the lack of originality was actually essential for successful communication. The keywords of allegorical drama were performativity and agency: thanks to their ability to incarnate ideas in living bodies, the moral plays aimed to impact the spectators' minds so deeply that the spectacle would shape their perceptions and opinions. Allegorical drama was clearly conceived and used as a Medium, one as efficient as possible.

However, this description raises at least two questions. How did the playwrights transmit the idea that allegorical drama was one of the most efficient way to communicate with the public and to influence its behaviour? Were allegorical plays performed during the $15^{\text {th }}$ and $\mathrm{I} 6^{\text {th }}$ centuries really efficient as a medium? I will try to argue that an archaeological approach can shed some light on both issues. It seems that the playwrights and the actors picked, more or less wittingly, some imaginary representations of an 'ideal' communication and some technical innovations that increased the capacities of Human Seeing, both easily recognizable for the public. They included them in their plays, either as plot components, as specific characters, or as stage props.

One of the most striking characterics of allegorical drama was indeed the choice of ordinary men as the plays' main characters. As their names suggest, 'The Man', 'Everyman', 'Mankind' embody the organisers, the actors, and the public together. These characters' way of life is flawed by the errors Christian men and women can commit in everyday life. Indeed, Mankind's most common problem is a permanent attention deficit disorder. He is light-headed, unable to recognize the allegories of Virtues and of Vices surrounding him, although their representations on the allegorical stage are quite transparent, and to detect the path to Heaven. The

7 The French Morality plays are currently edited in the Recueil général de moralités en français [20]; for a general survey, see Doudet [12]. 
main issue of the moralités is clearly to demonstrate the imperfection of human vision, how incapacited the eyes are in front of the 'reality' - understood in the plays as a combination of Christian faith and moral conduct. The plays usually claim that the answer to this general problem is precisely to be found in allegorical drama itself, since it is able to teach men and women not only how to behave, but first and foremost how to watch and thereby improve themselves.

A second striking tendency in Medieval French allegorical drama follows from this objective. In order to focus the attention of the spectators on their blindness and to convince them that theater is the necessary medium to acquire a clearer vision, the fictional characters on stage are being provided with technical devices that improve their visual perception. These devices could be books, operating as instruments of revelation when carefully read, or optical tools such as mirrors and eyeglasses.

In Well-Advised and Ill-Advised [Bien Advisé, Mal Advisé], one of the most famous French morality plays of the $15^{\text {th }}$ century, Faith reminds Well-Advised that a lucid way of seeing the world - in other words, a moral and allegorical way of deciphering it - is crucial for Mankind's life and for his redemption after-life. But however important optical apparatuses are for him, the Man is reluctant to accept them:

\section{FAITH}

Ha, Light is of great importance

For anyone who wants to walk safely.

When the vision starts to be blurry

One must put on his glasses quickly.

\section{WELL-ADVISED}

My lady, I see clearly,

I do not need glasses [I, p. 62-96 $]^{8}$.

The offering of spectacles, the presenting of mirrors, or the invitation to read books became progressively visual commonplaces in French Morality plays. When Guillaume des Autels, Joachim du Bellay's friend, composed a Moral Dialogue

8 Original quote: “Foy: A, bien fault avoir lumiere / Qui y veult aler seurement. / Quand la veüe prent a troubler, / On est tantost a sez lunettes. Bien Advisé: Madame, je voy assez cler, / Je n'ay que faire de lunettes" [5, pp. 64-65, vv. 438-443]. 
in I550, he concluded it with a scene where Truth gives Time a book. Ignorance, whose wrongdoings have escaped the light-headed Time until then, expresses his concerns about the new visual and intellectual capacities the allegory of Mankind might acquire through this dangerous medium:

Time and Truth act as if they look into the book, and

\section{IGNORANCE says}

That is not a good sign for me?

When Time looks up, Ignorance has disappeared from the stage. The blindness allegorized by Ignorance was no longer visible to those, Time and the public, whose vision was shaped by allegorical drama. Such scenes were concrete metaphers inviting the spectators to watch - and hopefully to grasp - the way they must look: look not only at the fictional world presented by the theater, but also at the real world through the theater. The stage operates as an optical apparatus, correcting the inefficiency of human vision by the allegorical art of showing the invisible.

One can perceive how this commonplace is still, in some ways, active in many audiovisual media of the $2 \mathrm{I}^{\text {th }}$ century, which legitimate their use in presenting themselves as necessary tools to access a virtual reality escaping the normal eyes ${ }^{10}$. But the archaeological survey to which the topos is inviting us must not be reduced to its potential in modern posterity. In the $15^{\text {th }}$ century, it was already part of a cultural memory and deep-rooted in two fields of knowledge developed and connected to each other during the $13^{\text {th }}$ century: the optical science and the art of preaching. Playwrights of allegorical drama in the $15^{\text {th }}$ and $16^{\text {th }}$ centuries were still familiar with this culture mixing science, theory, art and media. In some morality plays, the allegorical characters quote the De oculo morali by Pierre de Limoges and ask specifically to be watched by the 'moral eye' theorized in this treaty ${ }^{\text {II }}$.

The De Oculo morali popularized optical allegory at the end of the $13^{\text {th }}$ century. Its author, Pierre de Limoges, was a scientist who collaborated to the Pers-

\footnotetext{
9 Original quote p. 89: "Le Temps et Verité font semblant de lire au livre et dit Ignorance: Ce n'est pas un bon signe pour moy."

Io Hence, for example, the current development of reality-enhancing cameras, holographic helmets, or augmented reality glasses.

II See for example Le Concil de Basle (I434) [23, p. 82]: The Church asks Council to look at her in the particular manner advised by the Treaty on the Moral Eye; then Council would recognize her as an allegory.
} 
pectiva by Roger Bacon and greatly contributed to dissemination of the new vision science and theories on perspective in continental universities ${ }^{12}$. He was also a clerk, who soon detected in the visual studies some interesting relations with the moral lessons of the preachers. According to Pierre de Limoges, optics aims to enhance human external vision through technical devices in the same way that preaching aims to enhance human internal vision in encouraging spiritual meditation. The two approaches are linked moraliter, like mirror and theater in later morality plays, they operate as possible allegories of each other:

Peccator quando est in peccato peccati sui tenebras non advertit, sed extra peccatum positus et lumine divine graci illustratus, tunc primo peccati magnitudinem et caliginem in qua fuit recognoscit (Pierre de Limoges, De Oculo morali, 6. I) ${ }^{\mathrm{I3}}$.

[The sinner, when he is immersed in his sins, do not perceive their darkness; but when he is pulled out of them and is illuminated by the divine grace, he acknowledges the importance of his faults and perceives the darkness that surrounded him.]

Optical theories, such as perspective and optical apparatuses, such as glasses, were innovations that developed with great success during the $14^{\text {th }}$ and the $5^{\text {th }}$ centuries. It has often been noted that their dissemination accompanied the increase of and the changes in the visual arts, especially painting and drama. The connections between the rise of the visual arts and the sciences, on the one hand, and a set of flourishing social and cultural practices, including the preaching and its meditation techniques, on the other, have more recently drawn the historians' attention ${ }^{\mathrm{I} 4}$. Media Archaeology complements this comprehensive approach in demonstrating that these connections shaped a coherent media culture. Both a performing art resembling a sermons and a visual art employing optical apparatuses as stage props, allegorical drama summarized the objectives of these former media, as recalled by Guillaume des Autels in his I55I definition of moralités:

12 See [9, p. 329-343; Io (esp. chapter 3)].

13 Quote in [26, p. 682-703]; my translation.

14 See in French [28]; in English [8]. 
Their goal is to demonstrate the intellectual and invisible things through visual and sense-based ones ${ }^{15}$.

However it would be a mistake to consider that this media culture, sometimes defined as the Pre-Modern Media / Visual Culture [29], was static and unchanging until the $\mathrm{I} 7^{\text {th }}$ century. During the $\mathrm{I} 530 \mathrm{~S}$, when religious reform became a public issue in many French-speaking regions, including Switzerland and the Southern Low Countries, allegorical drama was often chosen as a battlefield by playwrights to strenghten the new convictions of their audiences [II, p. I99-2I2]. The optical apparatuses common on allegorical stages have been kept by the Reformists, but they operated in a very different way.

A character wearing glasses appears at the beginning of The Comedy of the Sick Pope by Conrad Badius, a play performed in Geneva in I56I. The scene is common in an allegorical Comedy following the codes of the morality play; except here the spectacle wearer is the Devil:

\section{SATAN}

Come, come, my dirty spectacles,

I meant my dear spectacles,

I will put you on my nose ${ }^{\mathrm{I}}$.

On the Protestant stage, the eyeglasses are dirty. They no longer could help to decipher the world, nor to discover the power of the Scriptures. Rather, they are used by Satan to read aloud to the Pope a list of the atrocities commited against the followers of the New Faith. The public of Geneva is invited to repel this evil optics, and, watching the Comedy with the right glasses, to support its denunciation of the Catholics' blindness.

How to measure the efficiency of a past medium? Allegorical drama and its reception

I5 Original quote: "Demonstrer les choses intelligibles et occultes par les sensibles et manifestes" [2, f. 63-64].

I6 Original quote: "Satan: Or ça, ça, venez mes maunettes / (Je voulais dire mes lunettes) /

Que je vous pose sur mon nez" [3, p. 223, v. 33-38]. 
If the playwrights of the $15^{\text {th }}$ and $16^{\text {th }}$ centuries constantly insisted on the peculiarities of the art they promoted, they were aware that theater was part of a far more complex audiovisual and verbal culture. Preachers, painters, weavers of tapestries, and other performers who participated in many ways to the public instruction were driven by the same ambition: to convince the public to adhere to the values of the community. Within this framework, texts, paintings, songs and plays were strongly connected. They often shared identical themes and were enacted in the same occasions. As Laura Weigert has recently demonstrated [33], in Western regions such as France, the $15^{\text {th }}$ and $16^{\text {th }}$ centuries were a time when intermediality was particularly powerful. It contributed to the success of a common media culture; but it also created opportunities to compare media with each other and to enhance the competition among them.

The first play entitled moralité in French, the Moral play for Saint Anthony's Feast (La Moralité du jour saint Antoine), performed by students in a Parisian college in I427, developed this topic. A Doctor addressing the audience in the Prologue explained the play's two objectives: to incitate the public to reject sins, and to demonstrate that theater is superior to written texts, discourse or inaminate figurations as a medium. The Doctor underlines that, in the $\mathrm{I} 5^{\text {th }}$ century, public communication and public moral education are key-issues. Education books and Holy Scriptures are displayed in bookshops. Preachers are active all around the city:

\section{THE DOCTOR}

People are preaching, yelling, advertising,

The Evil is denounced everyday,

Everyone makes all effort to speak against him....

But these communication efforts are for naught since people's attention is captured by too many media. According to the Doctor, Written and Oral communication are unable to impact the public's mind the way exemplary figures do:

\section{THE DOCTOR}

So says saint Gregory:

'Things exposed through exemplary figures

I7 Original quote: “Le Docteur: On presche, on crie, on admoneste, / Il n'est mal qui ne viengne en place, / D'en parler on se ront la teste” [20, v. 9-Io]. 
Are able to move and to stay in the memory

More than empty words's8.

Furthermore, the incarnation of abstractions into living bodies has a strong impact on the invisible forces embodied on stage, as well as on the spectators' mind. In normal circumstances, Sin draws its power from its invisibility. But when Sin takes the form of a human body on stage, it is forced to submit to the allegorical codes. He must reveal himself directly to the public and denounce who he is, like a Preacher would do, but with a far greater efficiency:

\section{SIN}

I speak like a Preacher;

I hate myself for it,

but I must obey ${ }^{\text {I9. }}$.

Underlining from its very beginning in French that it operates as a textual, a verbal and a visual art, Medieval allegorical drama demonstrated that visibility was efficiency and that, in this respect, the medium was the message.

One might ask whether this claim was or not supported by the public's actual reactions.

The reception for Medieval allegorical drama is certainly difficult to assess. French morality plays are today kept in manuscripts or in printed books that were, for most of them, intended for readers. Such material usually contain, limited information about the performances. On the other hand, when documents are preserved, they could be biaised, either because the witnesses gave testimonies that suit their particular purposes, or because the investigations took place when a scandal broke. Two cases in $1562-1563$ enable us to measure the difficulties and the limits imposed on archaeological approaches to past communication situations.

In I562, Conrad Badius' Comedy of the Sick Pope, whose cunning use of visual commonplaces has been previously analysed, was performed in Grenoble, a city close to Geneva and open to the Calvinist Reformation's influence.

I8 Original quote: "Le Docteur: Dit ainsi saint Gregoire: / Choses par exemples monstrees / Meuvent et sont plus a memoire / Que paroles tantost passees” [20, p. 6I-64].

I9 Original quote: "Pechié: Je dy ce que les prescheurs font, / De quoy je me doy bien haïr, / Mais il me convient obeïr” [20, v. 330-332]. 
Among the students attending the performance was the young Soffrey de Calignon. He explained later to his companions he was so shocked to see the Pope and the Catholic priests manipulated by the Devil that he decided to convert:

I have heard the Lord Chancellor say that he developed an interest towards Reformation when he was I2 or I3 and attended in Grenoble the performance of the Sick Religion <...>; that he got his first religious sentiments from this comedy ${ }^{20}$.

Soffrey de Calignon became one of the most proeminent companions to King Henry IV and drafted the Edict of Nantes granting to the French Protestants the freedom to practice their faith in I598. In this perspective, the document has an obvious hagiographic dimension and should be analysed with caution. The testimony is also clearly influenced by two commonplaces, powerful then and still active today: the disclosure of Truth by allegorical spectacle and media-induced religious conversion $^{21}$.

Another scandal broke out in 1563 in Mouvaux, a suburb of Lille, where the Protestant Moral Play The Hidden Truth [La Vérité Cachée] was performed. Written by an anonymous Swiss playwright in the I530s, this polemic text has been printed several times and widely circulated in Protestant circles in France, the Southern Low Countries and in England ${ }^{22}$. The inhabitants of Lille, especially local authorities and wealthy families, were at that time partly converted to Reformation. It was obviously the case for the organizers and actors of The Hidden Truth in Mouvaux, who were sons of notables:

Jean Boussemare, son of the Commissioner of Mouvaux, kept the play's script; his brother Pierre Boussemare played Truth; Michiel Cardon, son of the

\footnotetext{
20 Original quote: "Avoie ouy dire au Seigneur Chancelier qu'il en eust les premiers sentimens [de la religion réformée] environ la douziesme ou treiziesme annee de son age, auquel temps il ouist a Grennoble $<\ldots>$ la Religion mallade; et que ce fust en ceste comedie ou il prist sa premiere tainture" [32; p. 375].

2I The commonplace, reinforced in English Culture by Hamlet's influence, is illustrated by the novel Morality Play by B. Unsworth (Hamish Hamilton, 1995): in a village where a crime has been committed, actors played a Medieval Moral Play that will discover the truth.

22 La Verité cachée [Neuchâtel: P. de Vingles, I534; Geneva: A. Cercia, I555]. A translation in English has circulated in the I550s under the title Somebody and Others. See [I4].
} 
City Councillor, played the Catholic Priest; his brother Antoine Cardon was Greed; Louwys Prevost was Simony and Jacque Lortior the People ${ }^{23}$.

According to the witnesses questionned by the police, around I500 spectators attented the play. Most of them supported its attacks against Catholicism, while the others loudly condemned it. After the actors were arrested, the priests of Mouvaux and Tourcoing were heard to explain what, in their eyes, happened. A comparison of the play's printed text and their testimonies raises interesting questions about the efficiency of allegorical drama as medium in a polemical context.

The Hidden Truth stages six characters: a corrupted Catholic Priest who gags and throws Truth in jail ; Greed and Simony who support the Priest's coup and try to convince the credulous People; and Somebody, who takes a critical stand against the villains. The judicial register also recorded six actors arrested after the performance. Yet none of the witnesses remembered the exact number of the characters they have observed:

Immediately started a new play that presented, as far as the witness can recall, four characters, Truth, the Church Minister dressed as a Priest, Greed and Simony. (Pierre Famelaert, Priest in Tourcoing) ${ }^{24}$.

A new play that presented, as far as the witness can recall, five characters: Truth, a Minister dressed as a Priest, Greed, Simony and the People. (Alexandre Damon, Priest in Mouvaux) ${ }^{25}$.

The spectators' testimonies seem to demonstrate that allegorical drama, despite all its theories about theatrical performativity and ideal communication,

23 Criminal Register in Brussels, Royal General Archives, I734.2, ff. I23-I26v, published by K. Lavéant, 2I. Original quote: “Jehan Boussemare, fils du bailli de Mouvaux, tenoit l'originel; Pierre Boussemare son frere jouwait la personne de Verité; Michiel Cardon, fils de l'échevin, estoit le Ministre; Antoine Cardon, son frere, Convoitise; Louwys Prevost estoit Simonie et Jacque Lortior le Peuple" [2I].

24 Original quote: "Fut incontinent jouwé ung aultre jeu auquel selon la memoire du parlant estoient quatre personnaiges principalles assavoir Verité, le Ministre de l'Eglise accoustré en prestre, Convoitisse et Simonie" [2I].

25 Original quote: "Un aultre jeu qui <...> contenoit selon la memoire du parlant cincq personnaiges, Verité, le Ministre accoustré comme ung prestre, Convoitise, Simonie et le Peuple" [2I]. 
was not the efficient medium it claimed to be. But some other reasons for this blindness should be pointed out. Firstly, according to the witnesses, the scenic action was difficult to follow because the performance was disturbed by shouting:

The witness could not perceive clearly the lines said on stage because people were making noise. (Pierre Famelaert, Priest in Tourcoing) ${ }^{26}$.

Furthermore, it is likely that at least one actor, maybe Jean Boussemare, played two parts, the role of Somebody and that of the stage director (the register indicates that he 'kept the script'), a fact that might have caused some confusion for the spectators.

Since almost all the witnesses interviewed omitted to mention the People and Somebody, we might explain their invisibility based on the specific type of communication allegorical drama promoted. As previously demonstrated, moral plays invited the spectators to look at themselves when they looked at the fictional characters on stage, especially when the characters allegorized 'Everybody'. In The Hidden Truth, this is the case for the People, an incarnation of the naive, ill-informed general public, and for Somebody, the personification of the Protestant spectators. The men whose testimonies were recorded by the Ecclesiastical Justice were Catholic Priests. They were able to perceive the shocking staging of themselves but not the characters embodying the Others, those who were already convinced by the play's message and supported its controversial debate against the priests. Allegorical drama might have been, after all, a very efficient medium, if indeed, thanks to its wide dissemination during the $15^{\text {th }}$ and $16^{\text {th }}$ centuries, it has successed in shaping the spectators' vision, teaching them what was to be seen and believed, and what was not.

Analysing Medieval theater through the approach offered by Media Archaeology would be surprising if the word 'media' is defined exclusively from the technological point of view which is usual in the $2 \mathrm{I}^{\text {st }}$ century. Yet, when they aimed to highlight the evolutions and the innovations in Western Media cultures and practices, Jay David Bolter and Richard Grusin studied as examples of 'new media' a Prayer Book of the $5^{\text {th }}$ century and an advertising poster of the I960s [6, p. I5].

26 Original quote: "Ne pouvoit bonnement entendre les chapitres pour le murmure du peuple" [2I]. 
In their eyes, both documents were valid illustrations of various forms of 'mediality': the immediacy, when the medium hides its communication system to its audience; and the hypermediacy, when the medium openly displays the way it operates.

Many Medieval cultural productions fall within the latter case. Among them, allegorical drama is probably one of the most striking examples of an early 'hypermediacy'. This does not mean that the identities and the motives of the agents involved in the performances are always documented and can be easily deciphered today. But communication was frequently the main topic of this pedagogical art. The moral plays aimed to demonstrate their own power of persuasion in staging communicative situations as they came into being, from the initial lack of attention on the part of the main characters, to the revelations promised to those whose vision was enhanced by optical techniques. Theses techniques, in turn, were transparent metaphers for the theater itself, an art that could go beyond appearances. The tensions in Medieval allegorical drama between the abstract ideas and the living bodies that incarnated them, the visible and the invisible, reality and virtuality, encourage us to put in perspective the most recent (r)evolutions in our own culture.

Media Archaeology offers today an innovative path to study the connections as well as the ruptures between past and present practices of communication, and to better grasp their differences and convergences. As I hope my articulation of the case might have demonstrated, Medieval 'Mediality' could in turn help to expand and to enhance this new field of research. 


\section{References}

I Des Autels G. Dialogue Moral. In Repos de plus grand travail. Lyons, J. de Tournes \& G. Gazeau, I550. (In French)

2 Des Autels G. Réplique de Guillaume Des Autelz aux furieuses défenses de Louis Meigret. Lyons, J. de Tournes \& J. Gazeau, I55I. (In French)

3 Badius C. La Comedie du Pape Malade (I56I). La Comédie à l'époque d'Henri II et de Charles IX, I, 7, eds. E. Balmas \& M. Barsi. Firenze/Paris, L. Olschki, I995.

(In French)

4 Bakhtin M. M. Rabelais and His World, trans. H. Iswolsky. Cambridge, The MIT Press, I969. 484 p. (In English)

5 Bien Advisé, Mal Advisé, Recueil général de moralités d'expression française. Ed. J. Beck. Paris, Garnier, 20I4. (In French)

6 Bolter J. D., Grusin R. Remediation. Understanding New Media. Cambridge, The MIT Press, I999. 295 p. (In English)

7 Bourdieu P. The Rules of Art, Genesis and Structure of the Literary Field. Trans. S. Emanuel. Stanford, Stanford University Press, I996. (In English)

8 Brantley J. Reading in the Wilderness, Private Devotion and Public Performance in Medieval England. Chicago, Chicago University Press, 2007.344 p. (In English)

9 Clark D.L. Optics for Preachers: the De Oculo Morali by Peter of Limoges. Michigan Academician, no 9/3, 1977, pp. 329-343. (In English)

Io Denery D.G. Seeing and Being Seen in the Later Medieval World. Cambridge, Cambridge University Press, 2005. 206 p. (In English)

II Doudet E. Les moralités 'polémiques' aux XVe et XVIe siècles, fonctionnement d'un système de communication. Polémique et rhétorique de l'Antiquité à nos jours.

Eds. Nicolas L., Albert L. Louvain-la-Neuve, De Boek. Duculot, 20IO, pp. I99-2I2. (In French)

Doudet E. Moralités et jeux moraux en français, $X V^{e}-X V I^{e}$ siècle. Paris, Garnier, 2017. (In French)

I3 Foucault M. The Archaeology of Knowledge. Trans. A. M. Sheridan Smith. London, New York, Routledge, 2002. 246 p. (In English)

I4 Houle P. A Reconstitution of the English Morality Fragment Somebody and Others. Papers of the Bibliographical Society of America, 71, 1977, pp. 259-277. (In English)

I5 Huhtamo E. Illusions in Motion. Media Archaeology of Panoramas and related spectacles. Cambridge, The MIT Press, 20I3. 438 p. (In English)

I6 Iser W. The Act of Reading: A Theory of Aesthetic Response. Baltimore and London, The Johns Hopkins University Press, I978. 239 p. (In English)

I7 Jauss E.R. Toward An Aesthetic of Reception. Trans. T. Bahti. Minneapolis, Minneapolis University Press, I982. 23I p. (In English)

I8 Kittler F. The Truth of the Technical World, trans. E. Butler. Stanford University Press, 20I4. 400 p. Berlin, Suhrkamp Verlage, 20I3. (In English) 
I9 Kittler F. Optical Media. Cambridge, Polity Press, 20IO. 250 p. (In English)

20 La Moralité du jour saint Antoine, ed. E. Doudet. Recueil général de moralités d'expression française. Paris, Garnier, forthcoming 20I7. (In French)

2I Lavéant K. "Le théâtre du Nord et la Réforme dans les villes francophones des PaysBas méridionaux". Le Théâtre polémique, I450-I550. Eds. J. Koopmans, K. Lavéant, M. Bouhaïk-Gironès. Rennes, PUR, 2008, pp. I6I-I78. (In French)

22 La Verité cachée, Neuchâtel, P. de Vingles, I534; Geneva, A. Cercia, I555. (In English)

23 Les origines du théâtre réformiste et partisan en France. ed. J. Beck. Leiden, Brill, I979. (In French)

24 McLuhan M. Understanding Media. Cambridge, The MIT Press, I994. 392 p (In French).

25 Media Archeaology, Approaches, Applications and Implications. Eds. E. Huhtamo, J. Parikka. Berkeley, University of California Press, 20II. 368 p. (In English)

26 Newhauser R. "Roger Bacon, Peter of Limoges and the Tractatus moralis de oculo". Nach der Veruteilung von I277. Berlin, De Gruyter, 200I, pp. 682-703. (In English)

27 Parikka J. What is Media Archaeology? Cambridge, Polity Press, 20I2. 200 p. (In English)

28 Prédication et performance du XIIe au XVIe siècle. Eds. M. BouhaikGironès M., M.-A. Polo de Beaulieu. Paris, Garnier, 20I3. (In French)

29 Surgers A. L'Automne de l'Imagination. Splendeurs et misères de la représentation (XVI $-X X I^{e}$ siècle). Bern, Peter Lang, 20I2. (In French)

30 Jauss H.-R. “Theorie der Gattungen und Literatur des Mittelalters”. Grundriss der romanischen Literaturen des Mittelalters, I972, pp. I07-I38. (In German)

3I Usher P. On The Exterranean: Towards an Ecology and a Phenomenology of Extraction in the Humanist Anthropocene, forthcoming 20I7. (In English)

32 Vie et poésies de Soffrey de Calignon, chancelier du roi de Navarre, ed. Cte Douglas. Grenoble, I874. (In French)

33 Weigert L. French Visual Culture and the Making of Medieval Theater. Cambridge, Cambridge University Press, 2015. 305 p. (In English)

34 Zielinski S. Deep Time of the Media, Toward an Archaeology of Hearing and Seeing by Technical Means. Trans. G. Custance. Cambridge, The MIT Press, 2008. 375 p. (In English) 